\title{
HABITAT SELECTION BY THE PYGMY RABBIT (BRACHYLAGUS IDAHOENSIS) IN NORTHEASTERN UTAH
}

\author{
Jennifer M. Schmalz ${ }^{1,2}$, Barbara Wachocki², Masako Wright ${ }^{3}$, \\ Samuel I. Zeveloffl', and Michele M. Skopec ${ }^{1,4}$
}

\begin{abstract}
The pygmy rabbit (Brachylagus idahoensis), the world's smallest rabbit, has a limited distribution due to its year round dependence on sagebrush (Artemisia tridentata) for food and shelter. Due to accelerating habitat loss from fragmentation, development, and fire, understanding the pygmy rabbit's ecology has become increasingly important. In 2010, we initiated a study of the status of a pygmy rabbit population and its habitat requirements on U.S. Bureau of Land Management (BLM) land near Woodruff in northeastern Utah. We first observed and recorded the presence of the rabbit and its use of the area, and then measured sagebrush height, density, cover, and major and minor crown widths at active burrow and potential burrow sites. We also compared understory characteristics and soil texture at active, recently abandoned, and potential burrow sites. Pellets and sagebrush samples were also analyzed to determine dietary patterns. The height, as well as the major and minor crown widths of the sagebrush, and 2 cover measurements were significantly greater at active burrow sites than at potential burrow sites $(P<0.001)$. Total grass and forb biomass differed between the sites, with active burrow sites having higher total biomass in the spring compared to abandoned and potential burrow sites $(P<0.05)$ and higher total biomass in the fall compared to abandoned sites $(P<0.05)$. The principle component of the soil at all sites was sand, with small amounts of silt and clay. The pygmy rabbit's annual diet consisted of $80.7 \%$ sagebrush, and the sagebrush chosen for consumption was higher in crude protein and lower in fiber than nonforaged sagebrush. Our results suggest that maintaining stands of large mature sagebrush will provide pygmy rabbits in this area with preferred burrow and foraging sites that are vital to the persistence of populations in this region.
\end{abstract}

RESUMEN.-El conejo pigmeo (Brachylagus idahoensis), el conejo más pequeño del mundo, tiene una distribución limitada debido a su dependencia a la artemisa (Artemisia tridentata) durante todo el año, para su alimentación y refugio. Debido a la acelerada pérdida de su hábitat causada por fragmentación, desarrollo y fuego, se ha vuelto cada vez más importante comprender su ecología. En 2010, iniciamos un estudio de la situación de una población de conejo pigmeo y sus requisitos de hábitat en US Bureau of Land Management (BLM) cerca de Woodruff en el noreste de Utah. En primer lugar, observamos y registramos la presencia del conejo y su uso de la zona y luego medimos: altura de la artemisa, densidad, cobertura y el tamaño de su corona mayor y corona menor en madrigueras activas y posibles sitios de madrigueras. Comparamos las características del sotobosque y la textura del suelo en los sitios de madrigueras activas, recientemente abandonadas y posibles sitios de madrigueras. También analizamos muestras de heces y de artemisa para determinar los hábitos alimenticios. La altura, así como los anchos de la corona mayor y menor de la artemisa y dos medidas de la cubierta fueron significativamente mayores en sitios activos comparados a posibles madrigueras $(P<0.001)$. La hierba total y la biomasa de herbáceas fueron diferentes entre los sitios con madrigueras activas, que tienen mayor biomasa total en la primavera, en comparación con los sitios de posibles madrigueras y abandonadas $(P<0.05)$ y una mayor biomasa total en el otoño en comparación con los sitios abandonados $(P<0.05)$. El componente principal del suelo en todos los sitios era arena con pequeñas cantidades de limo y arcilla. La dieta anual del conejo pigmeo consistía en $80.7 \%$ de artemisa y la artemisa elegida para el consumo fue mayor en proteína cruda y baja en fibra que la artemisa no consumida. Nuestros resultados sugieren que el mantenimiento de lugares de artemisa grande y madura brindará mejores madrigueras y sitios de forrajeo, que son vitales para la persistencia de las poblaciones de conejo pigmeo en esta región.

The pygmy rabbit (Brachylagus idahoensis) is endemic to the shrubsteppe landscape of the Great Basin and surrounding areas of the northwestern United States (e.g., Green and Flinders 1980a). The continued fragmentation and loss of the shrubsteppe ecosystem may lead to a decline in pygmy rabbit populations. The smallest lagomorph in the world, the pygmy rabbit, is a sagebrush specialist-dependent on big sagebrush (Artemisia tridentata) for both food ( $\geq 90 \%$ in winter, $\geq 50 \%$ in spring/summer) and cover (Green and Flinders 1980a, 1980b, Flinders 1999, Siegel Thines et al. 2004). The rabbits utilize burrow systems constructed under sagebrush plants to escape predation and find relief from harsh climatic changes

\footnotetext{
${ }^{1}$ Department of Zoology, Weber State University, 2505 University Circle, Ogden UT 84408.

${ }^{2}$ Department of Botany, Weber State University, 2504 University Circle, Ogden UT 84408

${ }^{3}$ Utah Division of Wildlife Resources, 515 E 5300 S, Ogden, UT 84405.

${ }^{4}$ E-mail: micheleskopec@weber.edu
} 
(e.g., Green and Flinders 1980b, Heady and Laundré 2005, Estes-Zumpf and Rachlow 2007). Because of the pygmy rabbit's dependence on sagebrush, conservation efforts will be facilitated by the study of the vegetation and dietary factors important in pygmy rabbit use of the shrubsteppe ecosystem (Heady and Laundré 2005).

The pygmy rabbit has special management considerations within certain areas of its distribution. Although its current distribution throughout the Great Basin (excluding the Washington population) is not considered threatened, the study and protection of the species is warranted because these rabbits are habitat specialists. The rabbits are dependent on the shrubsteppe habitat, and as this habitat is depleted, these rabbits are incapable of assimilating into another habitat type. Pygmy rabbits also play an important role in maintaining the shrubsteppe ecosystem and have been described as a keystone species; their extensive burrow systems are utilized by invertebrates and other vertebrates in these habitats, and they offer terrestrial and avian predators a dependable food supply (Flinders 1999).

Pygmy rabbits usually occupy thick stands of big sagebrush growing in deep sandy soil (Green and Flinders 1980a, White et al. 1982, Weiss and Verts 1984). Though much is known about the pygmy rabbit, a better knowledge of the species and how it uses and selects its habitat will provide an improved understanding of how to manage sagebrush steppe habitat that the rabbits rely upon (Rachlow and Svancara 2006). Prior to this study, a sagebrush removal project was planned on the public lands to reduce fuels and improve the rangeland for grazing. Consequently, there was a need to assess the distribution and habitat selection of pygmy rabbits in northeastern Utah to help guide management decisions for the multiple uses of the public land they inhabit.

Our goal was to examine the occurrence, habitat selection, and diet of pygmy rabbits in a portion of northeastern Utah to gain an understanding of the factors affecting their selection of an area for its burrows and food. We first assessed the habitat usage and geographic distribution of pygmy rabbits within our study area. We then surveyed sagebrush, understory plants, and soils at active burrows and potential burrow sites to determine the potential selection factors pygmy rabbits use when choosing a burrow site. Last, we performed a pellet analysis to determine the seasonal variation in the rabbits' consumption of sagebrush and compared nutrient and secondary compound composition of foraged and nonforaged sagebrush.

\section{Methods \\ Study Area}

The study area was located in northeastern Utah in the foothills of the Rocky Mountains in Rich County near the town of Woodruff $\left(41^{\circ} 31^{\prime} 2.82^{\prime \prime} \mathrm{N}, 111^{\circ} 15^{\prime} 29.87^{\prime \prime} \mathrm{W}\right)$. The study site was 1193 acres of grazed sagebrush habitat managed by the U.S. Bureau of Land Management (BLM). The elevation range was $2032 \mathrm{~m}$ to $2231 \mathrm{~m}$, annual average temperature was $3.6^{\circ} \mathrm{C}$, and average annual precipitation was approximately $25 \mathrm{~cm}$. The area was characterized by shrubsteppe vegetation, and the dominant shrubs included big sagebrush (Artemisia tridentata) and green rabbitbrush (Chrysothamnus viscidiflorus). Since pygmy rabbits have shown no significant preference for a particular subspecies of $A$. tridentata, we did not distinguish between those present (White et al. 1982). The understory consisted of a diversity of grasses and forbs, the most common grass being crested wheatgrass (Agropyron cristatum), which is a nonnative species. In addition to pygmy rabbits, other lagomorphs in the area included black-tailed jackrabbit (Lepus californicus) and mountain cottontail (Sylvilagus nuttallii).

\section{Population Distribution}

We conducted pygmy rabbit surveys in the spring and summer of 2010 . Nine transects were established at roughly 500-m intervals, running parallel to each other from north to south through the 1193 acre study area. The transects were $370-400 \mathrm{~m}$ long and $20 \mathrm{~m}$ wide (10 $\mathrm{m}$ on each side of a central line). The length of the 9 transects varied within a narrow range due to the perimeter shape of the study area. Each transect line was walked from left to right to left, $10 \mathrm{~m}$ on each side of the line. We continued this zigzag pattern across the area so that the entire area of the line was visually searched for burrows, pellets, and any other signs of pygmy rabbits. Each sign was marked for reference using a GPS. 
Burrows were categorized as active, recently active, old, very old, or excavated, based on commonly used criteria to evaluate burrow activity (Larrucea and Brussard 2008, Wilson et al. 2010, Pierce et al. 2011).

We also surveyed and identified areas of pygmy rabbit use by the presence of fresh, recent, or old pellets (e.g., Sanchez et al. 2009). Pygmy rabbit pellets are distinguished from those of other lagomorphs in the area by size; pygmy rabbit pellets are $4-6 \mathrm{~mm}$ in diameter (Larrucea and Brussard 2008). The pellet sizes of juvenile cottontails overlap those of pygmy rabbits, making it difficult to identify pellets by size. In such cases, we looked for other identifying features near the pellets, such as tall sagebrush, burrows, and signs of foraging on the sagebrush. Pellet age was differentiated between fresh, recent, and old by color. Pellets were considered fresh if they were damp, glossy, or dark to light green in color. Pellets were considered recent if they were a yellow-green to light yellow color, while old pellets were distinguished by a gray, weathered, crumbly appearance. Sanchez and her colleagues (2009) found that, aside from actual pygmy rabbit sightings, the combination of pellets and burrow systems provides the most reliable evidence of species occurrence in an area and may also provide an indirect index of population trends.

\section{Sagebrush Characteristics}

Vegetation measurements were taken at 40 active burrow sites that were chosen at random from the initial population abundance study done in the summer of 2009 . We established the presence of pygmy rabbits at each sampling site by direct observations of the rabbits or by the occurrence of fresh/recent pellets and recent excavation of the burrows. We also selected 40 potential burrow sites by going $50 \mathrm{~m}$ south of a corresponding active burrow. Although potential burrow sites fell within known pygmy rabbit home-range size, 37.2 to 67.9 ha, potential burrow sites were not utilized by pygmy rabbits for burrowing or foraging purposes (Heady and Laundré 2005). Each potential burrow site was searched for pellets, tracks, and other sign of the rabbits. Pygmy rabbit signs were never found at the potential burrow sites. Measurements were centered on the sagebrush plant that was directly over the pygmy rabbit burrow for active burrows or centrally located in a stand of sagebrush for potential burrow areas. Sagebrush height and widths of the major and minor crowns were recorded at each site. Density of the sagebrush was determined by recording the distance to the nearest sagebrush plant and the number of sagebrush present, irrespective of height or age, within circular $3 \mathrm{~m}$ radius plots that were centered on the central sagebrush plant.

Similar to the methods of Gabler et al. (2001), we estimated shrub cover by measuring the longest width of the living shrub crown (major crown) and the perpendicular width (minor crown). These 2 measurements were then used as the $\mathrm{X}$ and $\mathrm{Y}$ diameters of an ellipse to estimate cover area. These measurements were taken for the central sagebrush, as well as for each of the nearest sagebrushes in the 4 quadrants surrounding the central sagebrush.

Several analyses were used to determine if sagebrush characteristics differed between burrow and potential burrow sites. The 3 features of the central sagebrush (height, major crown, minor crown), the 2 density measures (distance to nearest sagebrush, number of sagebrushes in a 3-m radius), and the 2 cover measurements (area of the central sagebrush, closest sagebrushes in each quadrant) were directly compared between burrow and potential burrow sites using paired $t$ tests. The same 7 sagebrush characteristics were subjected to principle component analysis (PCA) to determine if burrow and potential burrow sites clustered separately. After PCA analysis, 2tailed paired $t$ tests were used to compare the resulting principal component variables for each site between burrow and potential burrow sites (Jolliffe 2005).

\section{Understory Characteristics}

During 2011 in spring, summer, and fall, 10 active, 10 recently abandoned, and 10 potential burrow sites were selected for an analysis of understory characteristics to investigate the temporal changes in grass and forb composition at these sites. Two perpendicular 30-m transects were centered at each site, and stakes were driven at the $0-\mathrm{m}$ and $30-\mathrm{m}$ ends. Possible sampling points were measured at 3-m intervals for a total of 21 points per site, at which we measured and collected the understory plants. Four of the 21 points at 
each burrow and potential burrow site were randomly chosen each sampling season, one in each cardinal direction. At each selected point, a $0.25-\mathrm{m}^{2}$ plot was established where all grasses and forbs were clipped, weighed, oven-dried, and weighed again.

The weight of grasses and forbs was compared between seasons and sites (active, abandoned, and potential burrow) by ANOVA, with the weight of grasses and forbs as the dependent variable and season and site as independent variables. Percent grass was calculated by dividing the weight of grasses for each collection site by the total weight of grasses and forbs at the site. Percent grass was arcsine square-root transformed to attain normality and analyzed by ANOVA, with percent grass as the dependent variable and season and site as independent variables. The total biomass of the understory grasses and forbs was compared between seasons and sites by ANOVA, with total biomass as the dependent variable and season and site as independent variables. Differences between individual means were determined by Tukey's honestly significant difference (HSD) analysis.

\section{Soil Composition}

We used a soil core sampling tube to collect soil cores from 12 active burrow sites, 11 abandoned burrow sites, and 11 potential burrow sites. Samples were collected $2 \mathrm{~m}$ south of each central sagebrush plant. The samples were stored at $20{ }^{\circ} \mathrm{C}$ until further analysis. Percent sand, silt, and clay were determined using the hydrometer method (e.g., Ashworth et al. 2001). Soil composition was compared between sites using ANOVA. Arcsine square-root-transformed percentages of sand, silt, and clay were the dependent variables, and site and soil component were the independent variables.

\section{Pellet Analysis}

Fresh pygmy rabbit pellets were collected from burrow sites in spring (March 2011, $n=$ 36), summer (June-August 2011, $n=24$ ), fall (October 2011, $n=8$ ), and winter (December 2011, $n=14$ ). Pygmy rabbit pellet appearance and size is dynamic, so the physical characteristics of the pellets were not the only factor examined during sample collection; other pygmy rabbit sign, such as burrows and evidence of foraging on sagebrush, were used.
Pellets were dried in a $50{ }^{\circ} \mathrm{C}$ oven and then ground and passed through a 1-mm screen. Ground samples were affixed to microscope slides using Permount Mounting Medium (Fisher Scientific), and 20 fields per slide at 50X magnification were visualized for plant fragments. Plant fragments found in feces were identified by comparison to reference slides of plant samples collected from the area (June-October 2011) that had been processed by the same protocol as the pellets. Relative percentages were calculated for each season, as in Flinders and Hansen (1972).

\section{Sagebrush Analysis}

In December 2011, seven sagebrush plants at the site were identified as foraged. Foraging was determined by the presence of fresh tracks and fecal pellets, as well as evidence of clipping by pygmy rabbits, as in Ulappa (2011). Samples were collected from the foraged sagebrush and from sagebrush that showed no signs of foraging $50 \mathrm{~m}$ to the south. Due to the large amount of sample needed for nutrient analysis (500 g), sagebrush foliage was collected from all parts of the plant and the nutrient data represent an average for the entire plant. Collected sagebrush samples were stored at $-20^{\circ} \mathrm{C}$ until sent to Dairy One in Ithaca, New York, for nutrient analysis. The percent dry matter, crude protein, acid detergent fiber, and neutral detergent fiber were determined, as well as the percentage of the micronutrients calcium, phosphorus, magnesium, potassium, and sodium, and the ppm of the trace minerals iron, zinc, copper, manganese, and molybdenum. Paired $t$ tests were used to compare all analyzed nutrients between foraged and nonforaged sagebrush.

Sagebrush samples were analyzed for 2 classes of plant secondary compounds known to deter herbivores: phenolics and monoterpenes. Sagebrush samples $(20 \mathrm{mg})$ were analyzed for total phenolics by using the Folin-Ciocalteu colorimetric reaction modified for a microplate reader, as described in Ainsworth et al. (2007). Sagebrush samples (5 g) were analyzed for total monoterpenes by using a colorimetric reaction described by Dimitriadis and Williams (1984). Paired $t$ tests were used to compare phenolic and terpene levels between the foraged and the nonforaged sagebrush. 
TABLE 1. Sagebrush characteristics at burrow and potential burrow sites. Means are given with standard errors in parentheses.

\begin{tabular}{lrrrrr}
\hline & & Potential & & \multicolumn{2}{c}{ Statistic } \\
\cline { 5 - 6 } Sagebrush characteristic & Burrow site & burrow site & $t$ & df & $P$ \\
\hline Features of central sagebrush & $98.3(4.8)^{*}$ & $55.6(3.2)$ & 6.6 & 78 & $<0.001$ \\
$\quad$ Height $(\mathrm{cm})$ & $123.1(7.1)^{*}$ & $75.7(5.4)$ & 4.7 & 78 & $<0.001$ \\
$\quad$ Major crown $(\mathrm{cm})$ & $89.7(6.0)^{*}$ & $54.3(4.5)$ & 4.2 & 78 & $<0.001$ \\
$\quad$ Minor crown $(\mathrm{cm})$ & $125.7(5.6)$ & $136.6(10.4)$ & 0.80 & 78 & 0.41 \\
Density measure & $23.5(1.2)$ & $23.4(1.8)$ & 0.03 & 78 & 0.98 \\
$\quad$ Distance to nearest sagebrush $(\mathrm{cm})$ & $334.1(19.4)^{*}$ & $204.3(14.5)$ & 4.8 & 78 & $<0.001$ \\
$\quad$ Number of sagebrush in 3-m radius & $1286.1(43.9)^{*}$ & $907.2(43.7)$ & 5.5 & 78 & $<0.001$ \\
Cover & & & & & \\
$\quad$ Area of central sagebrush $\left(\mathrm{cm}^{3}\right)$ & & & & &
\end{tabular}

*Denotes means that are significantly different within rows, $P<0.001$

TABle 2. Principle component loadings derived from PCA of sagebrush characteristics from burrow and potential burrow site locations.

\begin{tabular}{lrc}
\hline & \multicolumn{2}{c}{ Principle component } \\
\cline { 2 - 3 } Sagebrush characteristic & 1 & 2 \\
\hline Height $(\mathrm{cm})$ & 0.42184 & -0.01815 \\
Major crown (cm) & 0.45515 & 0.09268 \\
Minor crown $(\mathrm{cm})$ & 0.44281 & 0.1511 \\
Number of sagebrush in 3-m radius & -0.10004 & 0.6999 \\
Average distance to nearest sagebrush (cm) & 0.11916 & -0.67978 \\
Area of central sagebrush & 0.47337 & 0.12539 \\
Area of central sagebrush + nearest sagebrushes in all 4 quadrants & 0.41295 & -0.02365 \\
Percentage of variance explained & $59.20 \%$ & $22.10 \%$ \\
\hline
\end{tabular}

\section{RESUlTS}

Population Distribution and Habitat Characteristics

Pygmy rabbits were extant throughout our study area. We identified 41 live pygmy rabbits and one dead, 478 active burrow sites, 555 recently active burrow sites, 320 old burrow sites, and 389 very old burrow sites. In addition, 144 fresh, 568 recent, and 377 old pellet group locations were recorded.

Sagebrush at burrow sites were taller, had larger major and minor crown widths, and provided more cover than sagebrush at potential burrow sites (Table 1 , all $P$ values $<0.001$ ). There was no difference between burrow and potential burrow sites in the density measured by distance to the nearest sage or number of sagebrush in a $3-\mathrm{m}$ radius (Table 1 ).

Principle component analysis of the sagebrush characteristics revealed that the first 2 components explained $81 \%$ of the variation in the data (Table 2). Height, major and minor crown, and the 2 cover measurements had the highest loading in principle component 1 , and the burrow and potential burrow sites clustered separately (Fig. 1; $t=5.6$, df $=78, P<0.001$ ). The 2 density measures (distance to the nearest sagebrush and number of sagebrush in a $3-\mathrm{m}$ radius) had the highest loading in principle component 2 , and the burrow and potential burrow sites did not cluster separately $(t=1.5$, $\mathrm{df}=78, P=0.11$ ).

The masses of grasses and forbs differed seasonally $\left(F_{2,327}=38.724, P<0.001\right)$ and at the different sites (active, abandoned, and potential burrow sites; $F_{2,327}=3.634, P=0.027$; Table 3). Grasses were always in higher abundance than forbs at all sites in summer and fall $\left(F_{1,327}=23.931, P<0.001\right)$. In the spring, the active and the abandoned burrow sites had the same amount of grasses as forbs, while potential burrow locations had a higher amount of forbs than grasses, leading to a significant plant type by season effect $\left(F_{2,327}=10.896, P\right.$ $<0.001)$. The biomass of grasses was higher at active burrows than at potential burrow sites during spring $(P<0.05)$ and higher at active burrows than at abandoned burrow sites in the fall (all $P$ values <0.05). Grass biomass was 


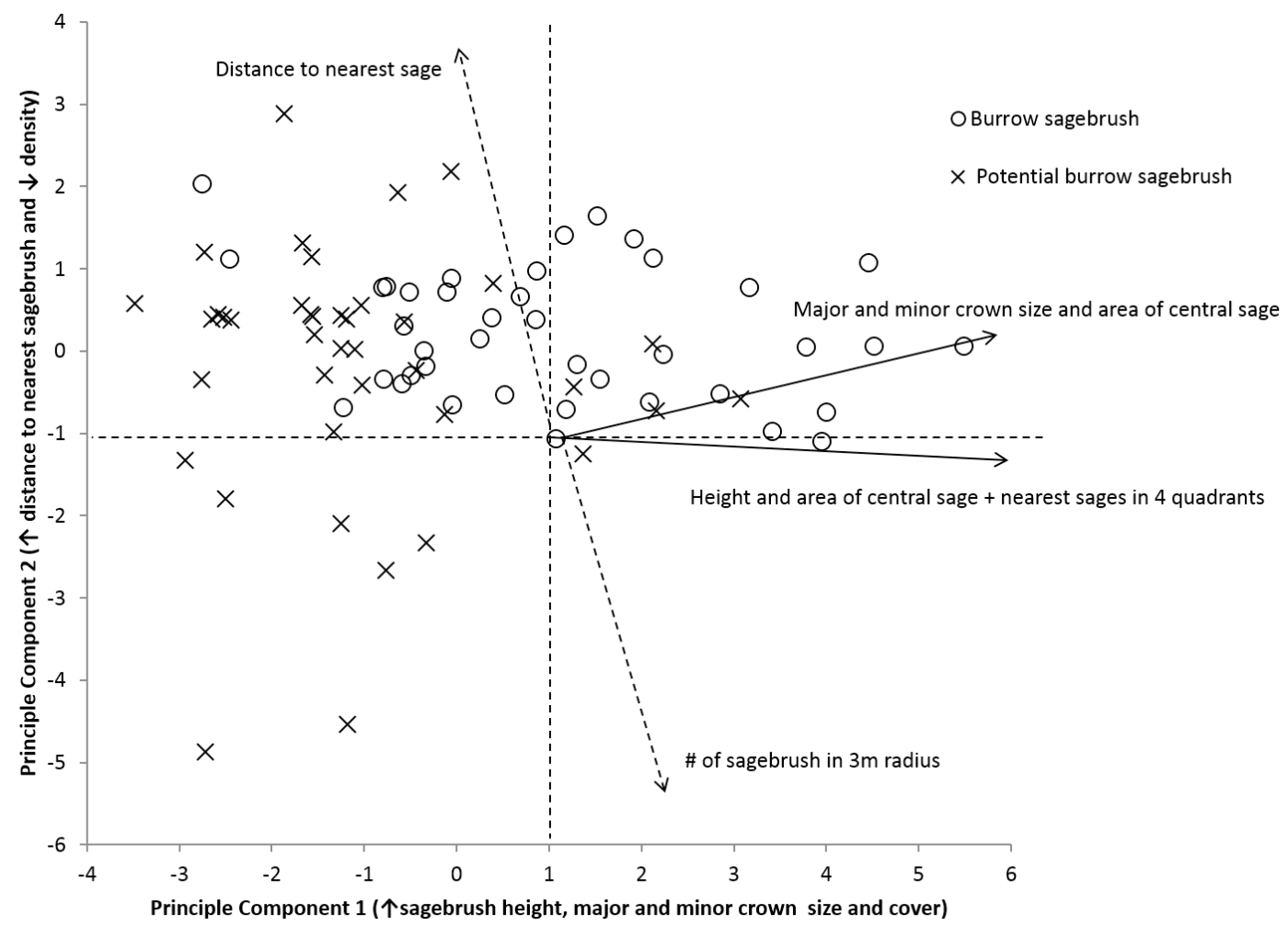

Fig. 1. Principle component analysis of sagebrush characteristics at burrow and potential burrow sites. Arrows with solid lines denote direction of drivers (height, major crown, minor crown, and cover) for principle component 1 , and dashed arrows represent direction of drivers (density measures) for principle component 2 . Burrow sites were significantly different from potential burrow sites for principle component $1(P<0.001)$ but not principle component $2(P=0.11)$.

TABLE 3. Seasonal changes in the percentage of shrubs, grasses, and forbs in pygmy rabbit diets as determined by pellet analysis.

\begin{tabular}{|c|c|c|c|c|}
\hline Diet component & $\begin{array}{c}\text { Summer } \\
\text { (Jun-Aug 2011) }\end{array}$ & $\begin{array}{c}\text { Fall } \\
\text { (Oct 2011) }\end{array}$ & $\begin{array}{c}\text { Winter } \\
\text { (Dec 2011) }\end{array}$ & $\begin{array}{c}\text { Spring } \\
(\text { Mar 2011) }\end{array}$ \\
\hline \multicolumn{5}{|l|}{ Shrubs } \\
\hline Artemisia spp. & 53.6 & 84.8 & 99.1 & 84.7 \\
\hline Chrysothamnus vicidiflorus & - & - & - & 0.5 \\
\hline TOTAL & 53.6 & 84.8 & 99.1 & 85.2 \\
\hline \multicolumn{5}{|l|}{ Grasses } \\
\hline Agropyron spp. & 36.9 & 10.6 & 0.9 & 9.4 \\
\hline Poa nevadensis & 4.6 & 1.6 & - & 3.8 \\
\hline Unidentified grass & 0.1 & - & - & trace \\
\hline TOTAL & 41.6 & 12.2 & 0.9 & 13.2 \\
\hline \multicolumn{5}{|l|}{ Forbs } \\
\hline Cryptantha fulvocanescens & 0.1 & 0.7 & - & - \\
\hline Lupinus spp. & 0.2 & 2.3 & - & 0.2 \\
\hline Penstemone humilus & 2.4 & - & - & 0.2 \\
\hline Phlox hoodii & 1.5 & - & - & - \\
\hline Trifolium spp. & 0.4 & - & - & 1.1 \\
\hline Unidentified forb & Trace & 0.1 & - & trace \\
\hline TOTAL & 4.6 & 3.1 & - & 1.5 \\
\hline
\end{tabular}



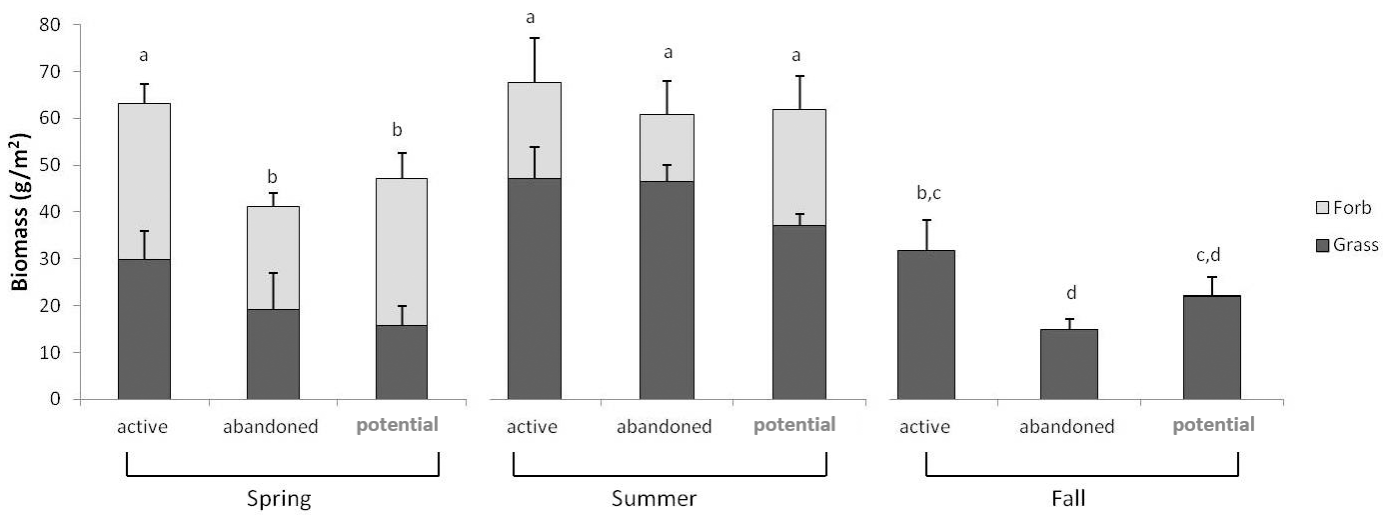

Fig. 2. Composition of understory biomass. Each bar represents the mean of forb and grass biomass at each site during each season. Whisker bars represent standard error. Letters denote means that are significantly different from each other as determined by Tukey's HSD test.

higher in the summer at all sites compared to both spring and fall (all $P$ values $<0.05$ ). Forb biomass did not differ between sites or between spring and summer. Forbs were absent from both active and abandoned sites in the fall and found in small quantities at potential burrow sites. Percent grass differed between the seasons $\left(F_{2,292}=83.780, P<0.001\right)$, with the highest value occurring in fall and the lowest in spring. There was no difference in the percent grass between sites $\left(F_{2,292}=\right.$ $0.262, P=0.769$ ).

Total biomass of the understory differed between seasons $\left(F_{2,327}=38.724, P<0.001\right)$, with the highest understory biomass occurring in the summer and the lowest in the fall (Fig. 2 ). Total understory biomass also differed between the sites $\left(F_{2,327}=3.634, P=0.027\right)$, with active burrow sites having higher total biomass in the spring compared to abandoned and potential burrow sites $(P<0.05)$ and higher total biomass in the fall compared to abandoned sites $(P<0.05)$.

All sites had soil that was primarily sand, with small amounts of silt and clay (Table 3). There were significant differences in the relative amounts of sand, silt, and clay in the soil within each of the 3 burrow types $\left(F_{2,93}=\right.$ 974.9, $P<0.001)$. However, there was no difference in the soil composition between sites $\left(F_{2,93}=0.011, P=0.99\right)$.

\section{Diet Analysis}

Pellet analysis revealed that sagebrush is a major component of the pygmy rabbit diet, ranging from a high of $99.1 \%$ in winter to a low of $53.6 \%$ in summer. On an annual basis, $80.7 \%$ of the pygmy rabbit's diet is sagebrush. Grasses were consumed in spring (9.4\%), summer $(41.6 \%)$, and fall $(9.4 \%)$. Forbs constituted $<5 \%$ of the diet in all seasons (Table 3). All pellets analyzed contained a minimum of $35 \%$ sagebrush, showing that our selection criteria led to an accurate selection of pygmy rabbit pellets, as cottontails utilize sagebrush for $<10 \%$ of their diets (MacCracken and Hansen 1984).

Foraged sagebrush was higher in crude protein $(P=0.05)$ and lower in acid detergent fiber $(P=0.01)$ and neutral detergent fiber $(P$ $=0.03)$ than nonforaged sagebrush (Table 5). There was no difference in the micronutrient levels of foraged and nonforaged sagebrush (Table 6). Foraged sagebrush was significantly lower in iron than nonforaged sagebrush $(P=$ 0.04 ; Table 7). However, there were no differences in the other trace minerals measured (Table 7). The amount of phenolics and terpenes did not differ between foraged and nonforaged sagebrush (Table 8).

\section{Discussion}

Pygmy rabbits are specialists that rely on sagebrush for both food and shelter. Based on our findings, pygmy rabbits in the Woodruff area are clearly selecting larger sagebrush plants for their burrow locations. Their active burrow sites also had higher amounts of grass and total understory biomass than abandoned burrow or potential burrow sites in the spring and fall. Thus, understory characteristics may 
TABLE 4. Grass, forb, and soil composition at active, abandoned, and potential burrow sites. Means are given with standard errors in parentheses.

\begin{tabular}{|c|c|c|c|}
\hline & Active burrow & Abandoned burrow & Potential burrow \\
\hline \multicolumn{4}{|l|}{ Grass weight $\left(\mathrm{g} \cdot \mathrm{m}^{-2}\right)$} \\
\hline Spring (Jun 2011) & $29.80(6.84)^{\mathrm{a}}$ & $19.20(3.48)^{\mathrm{a}, \mathrm{b}}$ & $15.76(2.53)^{\mathrm{b}}$ \\
\hline Summer (Aug 2011) & $47.08(6.08) *$ & $46.48(7.78)^{*}$ & $37.05(4.19)^{*}$ \\
\hline Fall (Oct 2011) & $31.76(6.55)^{\mathrm{a}}$ & $14.82(2.28)^{\mathrm{b}}$ & $21.92(4.29)^{\mathrm{a}, \mathrm{b}}$ \\
\hline \multicolumn{4}{|l|}{ Forb weight $\left(\mathrm{g} \cdot \mathrm{m}^{-2}\right)$} \\
\hline Spring (Jun 2011) & $33.39(9.47)$ & $21.95(7.24)$ & $31.31(7.18)$ \\
\hline Summer (Aug 2011) & $20.62(4.15)$ & $14.30(2.84)$ & $24.75(5.47)$ \\
\hline Fall (Oct 2011) & $0.00(0.00)^{*}$ & $0.00(0.00)^{*}$ & $0.22(0.22)^{*}$ \\
\hline \multicolumn{4}{|l|}{ Percent grass } \\
\hline Spring (Jun 2011) & $50.56(7.48)$ & $58.70(7.35)$ & $47.56(8.68)$ \\
\hline Summer (Aug 2011) & $67.94(4.97)$ & $68.32(5.07)$ & $67.08(5.11)$ \\
\hline \multicolumn{4}{|l|}{ Soil composition } \\
\hline$\%$ sand & $70.7(2.4)^{*}$ & $72.8(1.4)^{*}$ & $70.1(1.7)^{*}$ \\
\hline$\%$ silt & $17.2(1.9)$ & $15.6(1.2)$ & $17.5(2.3)$ \\
\hline$\%$ clay & $12.2(0.8)$ & $11.5(1.0)$ & $12.4(0.9)$ \\
\hline
\end{tabular}

*Denotes means that are significantly different within each column $(P<0.05)$

a,b Denotes means that are significantly different within each row $(P<0.05)$.

also play a role in their choice of burrow location. Sagebrush is the dominant plant in the diet year round, and pygmy rabbits forage on sagebrush with higher crude protein levels and lower fiber levels. The pygmy rabbits did not select sagebrush for foraging based on micronutrient, trace mineral, or plant secondary compound content. Although sample sizes were small for some measurements, we did find statistically significant differences.

\section{Habitat Characteristics}

Pygmy rabbit populations at other sites also prefer large sagebrush for their burrow sites (e.g., Green and Flinders 1980b, Weiss and Verts 1984, Gahr 1993, Katzner et al. 1997, Katzner and Parker 1998, Gabler et al. 2001, Larrucea 2008). Larger sagebrush should provide more cover to a small lagomorph which is highly susceptible to predation (Wilde 1978, Katzner and Parker 1998). On average, the central sagebrush at burrow sites provided $63 \%$ more cover than the central sagebrush at potential burrow sites (Table 1). Larger sagebrush may also provide more foliage for foraging close to burrow entrances, which may be preferable to pygmy rabbits, as they are central-place foragers and bring clipped sagebrush back to their burrows for consumption (Siegel Thines et al. 2004).

Sagebrush density also plays a role in the pygmy rabbit's habitat selection, and higher densities are preferred (Green and Flinders 1980b, Weiss and Verts 1984, Gahr 1993, Katzner et al. 1997, Katzner and Parker 1998,
Gabler et al. 2001, Larrucea 2008). Although we did not find a difference in sagebrush density at burrow and potential burrow sites, our results do not preclude sagebrush density as being an important determinant in pygmy rabbit habitat selection. The lack of difference in sagebrush density between burrow and potential burrow sites could be due to sagebrush density being uniformly high at our study site.

The amount of grasses and forbs differed through the seasons. Grass biomass was highest in the summer, which coincides with the highest incorporation of grass in pygmy rabbit diets $(41.6 \%$; Tables 3, 4). Other studies have found that overall grass density does not differ at burrow and potential burrow sites (Green and Flinders 1980b, Weiss and Verts 1984, Gabler et al. 2001) but that relative forb density tends to be higher at burrow sites, perhaps because pygmy rabbits preferentially forage on grasses over forbs (Green and Flinders 1980b, Gabler et al. 2001). In contrast, the grass biomass in our study area was almost 2 times higher at active burrow sites than at potential burrow sites in the spring and at abandoned burrow sites in the fall (Table 3, Fig. 1). Also, the pygmy rabbits at our site did preferentially forage on grass compared to forbs when both were available in the summer (Table 4), though we did not find differences in percent grass at the different sites (Table 3).

Active burrow sites had greater understory biomass in the spring compared to both abandoned and potential burrow sites, and greater understory biomass in the fall compared to 
TABLE 5. Nutritional composition of foraged and nonforaged sagebrush (\% dry matter). Means are given with standard errors in parentheses.

\begin{tabular}{|c|c|c|c|c|c|}
\hline \multirow[b]{2}{*}{ Nutritional component } & \multirow{2}{*}{$\begin{array}{c}\text { Foraged } \\
\text { sagebrush }\end{array}$} & \multirow{2}{*}{$\begin{array}{c}\text { Nonforaged } \\
\text { sagebrush }\end{array}$} & \multicolumn{3}{|c|}{ Statistics } \\
\hline & & & $t$ & $\mathrm{df}$ & $P$ \\
\hline \multicolumn{6}{|c|}{ Macronutrient composition (\%) } \\
\hline Dry matter & $54.4(1.2)$ & $55.1(2.1)$ & 0.3 & 7 & 0.74 \\
\hline Crude protein & $10.2(0.8)$ & $8.6(0.4)$ & 2.0 & 7 & 0.05 \\
\hline Acid detergent fiber & $29.2(0.9)$ & $32.8(1.3)$ & 2.5 & 7 & 0.01 \\
\hline Neutral detergent fiber & $41.8(1.1)$ & $45.3(1.4)$ & 2.3 & 7 & 0.03 \\
\hline \multicolumn{6}{|c|}{ Micronutrient composition (\%) } \\
\hline Calcium & $0.4(0.02)$ & $0.4(0.02)$ & 0.8 & 7 & 0.40 \\
\hline Phosphorus & $0.2(0.01)$ & $0.2(0.0)$ & 1.8 & 7 & 0.06 \\
\hline Magnesium & $0.1(0.02)$ & $0.1(0.01)$ & 0.1 & 7 & 0.90 \\
\hline Potassium & $0.9(0.03)$ & $0.9(0.03)$ & 1.3 & 7 & 0.20 \\
\hline Sodium & $0.01(0.0)$ & $0.01(0.0)$ & 0.3 & 7 & 0.80 \\
\hline \multicolumn{6}{|c|}{ Trace mineral composition $(\%)$} \\
\hline Iron & $87.7(6.5)$ & $140.0(21.1)$ & 2.2 & 7 & 0.04 \\
\hline Zinc & $21.0(2.1)$ & $17.9(1.2)$ & 1.3 & 7 & 0.20 \\
\hline Copper & $7.6(1.2)$ & $6.4(0.4)$ & 0.9 & 7 & 0.40 \\
\hline Manganese & $37.6(5.6)$ & $26.9(1.8)$ & 1.8 & 7 & 0.10 \\
\hline Molybdenum & $1.3(0.1)$ & $1.4(0.1)$ & 0.2 & 7 & 0.80 \\
\hline \multicolumn{6}{|c|}{ Plant secondary compound composition (\%) } \\
\hline Total phenolics & $3.0(0.9)$ & $3.2(0.1)$ & 1.0 & 7 & 0.40 \\
\hline Total terpenes & $1.7(0.1)$ & $1.9(0.2)$ & 1.0 & 7 & 0.40 \\
\hline
\end{tabular}

abandoned burrow sites (Fig. 1). Therefore, a lack of understory biomass and particularly grass may be a factor in burrow abandonment. Whether the pygmy rabbit or a competitor, such as the mountain cottontail rabbit, was the cause of the decreased understory biomass is not known. Mountain cottontails comprised approximately $40 \%$ of live animal observations at the site, and these rabbits would be dependent on understory plants for food, as they cannot subsist on sagebrush. Their presence has also been negatively correlated with presence of pygmy rabbits (Larrucea 2008, Larrucea and Brussard 2008). Finally, grazing cattle could be foraging on the understory, and pygmy rabbits avoid areas grazed by cattle (Siegel Thines et al. 2004).

Soil characteristics, such as depth, clay content, and sand content, will affect the pygmy rabbit's ability to burrow (Weiss and Verts 1984, Larrucea and Brussard 2008). Pygmy rabbits prefer habitats with loamy and friable soils (Weiss and Verts 1984) that do not have a reddish hue (Larrucea and Brussard 2008). While there were no differences in the percent sand, silt, and clay in the soil at active, abandoned, and potential burrow sites, all sites were predominantly sand $(\sim 70 \%$; Table 3$)$. Depth of soil was not measured and may be an important determinant of burrow sites. Deeper soil provides better burrowing habitats (Weiss and Verts 1984, Gabler et al. 2001, Larrucea and Brussard 2008), and such soil may also facilitate the growth of sagebrush plants (Ellison 1960, Larrucea and Brussard 2008). In our study, the sagebrush plants at burrow sites are larger and thus may be indicative of the deeper soils that are ideal for burrowing. The results of our soils study are preliminary, given the sample size in this part of the study; more research is needed to discern patterns of soil depth and sagebrush plant size.

\section{Dietary Characteristics}

Analysis of pellets showed that sagebrush was a major component of pygmy rabbit diets at the site in all seasons and that during the winter, 99\% of the diet was composed of sagebrush. We therefore chose to collect sagebrush in winter for nutrient analysis because it was the primary forage being consumed and the time is ideal for identifying foraged sagebrush because of the ease of following rabbit tracks between sagebrush and identifying the pygmy rabbit's unique clipping pattern (Ulappa 2011). Though sagebrush has been previously analyzed for crude protein, fiber, and plant secondary compounds, this is the first time to our knowledge that micronutrient and trace minerals have been analyzed. While the sample size for nutritional analysis was small $(n=14)$, there were still significant differences between 
foraged and nonforaged sagebrush in protein, fiber, and iron.

Pygmy rabbits have lower nitrogen requirements than cottontails and need only $3.5 \mathrm{~g}$ of crude protein daily for maintenance (Shipley et al. 2006). Despite this low requirement, the pygmy rabbits in the Woodruff area apparently still made foraging decisions based on crude protein levels. On average, foraged sagebrush was $16 \%$ higher in crude protein than nonforaged sagebrush (Table 5). Shipley et al. (2006) also found that pygmy rabbits have a higher energy requirement than cottontails, needing $1365 \mathrm{~kJ}$ of digestible energy daily for maintenance. The pygmy rabbit's higher energy needs may be driving selection for sagebrush that is lower in fiber. Foraged sagebrush was $11 \%$ lower in acid detergent fiber (a measure of cellulose and lignin levels) and 8\% lower in neutral detergent fiber (a measure of hemicellulose, cellulose, and lignin levels). Foraging for sagebrush that is higher in protein and lower in fiber, and therefore more "energy dense," may be especially important during winter when pygmy rabbit diets are 99.1\% sagebrush (Table 5) becuse energy needs are especially high for thermoregulation at cold temperatures (Katzner et al. 1997). Further study has been initiated to determine if larger sagebrush meet these foraging criteria (being higher in protein and lower in fiber) and if the pygmy rabbit foraging criteria for sagebrush change seasonally.

Micronutrient analysis revealed no differences between foraged and nonforaged sagebrush (Table 6). The sagebrush met the minimum dietary requirements of rabbits for calcium, phosphorus, magnesium, potassium, and sodium (National Research Council 1977). Micronutrient requirements for pygmy rabbits have not been investigated, but the lack of selection for micronutrient content in our study suggests that sagebrush is meeting the needs of pygmy rabbits.

Trace mineral analysis of the sagebrush revealed that foraged sagebrush was lower in iron than nonforaged sagebrush (Table 7). The iron requirements of rabbits are not known, but levels of iron in both foraged (88 ppm) and nonforaged (140 ppm) sagebrush are below that found in commercial rabbit chow (360 ppm: 2031 Teklad Global High Fiber Rabbit Diet). It is thus unlikely that the pygmy rabbits are avoiding sagebrush due to a high iron content.
None of the other trace minerals measured (zinc, copper, manganese, and molybdenum) were found in different concentrations in the foraged and nonforaged sagebrush, and all met the minimum dietary requirements for rabbits (National Research Council 1977).

Sagebrush may be avoided by other herbivores due to the presence of plant secondary compounds (PSCs) that act as feeding deterrents. Sagebrush contains 2 major classes of PSCs: phenolics and terpenes. Both classes of PSCs act as feeding deterrents due to both pre- and postingestive consequences. Most mammalian herbivores are dietary generalists and eat a variety of plants to prevent toxicosis from the high levels of PSCs that can be ingested by consuming a single species of plants (Freeland and Janzen 1974). Pygmy rabbits, however, are sagebrush specialists, and it has been hypothesized that they may preferentially forage on sagebrush that is lower in phenolics and terpenes. Yet, we found no difference between the total phenolic and terpene concentrations in foraged and nonforaged sagebrush (Table 8). Based on our results, pygmy rabbits are not avoiding PSCs in sagebrush. A recent study has found that compared to cottontail rabbits, pygmy rabbits have a highly effective detoxification mechanism for dealing with one of the terpenes present in sagebrush (Shipley et al. 2012).

\section{Management Implications}

Based on our findings, the most important management concern in the Woodruff area is maintaining the stands of large, mature sagebrush plants that are potentially higher in crude protein and lower in fiber to provide pygmy rabbits with preferred burrowing and foraging sites. In addition, maintaining grass levels in the understory to support pygmy rabbit diets in the summer months is warranted.

\section{ACKNOWLEDGMENTS}

We appreciate the Utah Division of Wildlife Resources, the U.S. Bureau of Land Management-in particular BLM biologist Traci Allen-and Weber State University for their logistical support and funding for this project. We thank the following for assistance in the field and laboratory: Jordan Hyde, Heidi Semper, Aaron Ogden, Susan Gurr, Andrew Corbin, Stephen Clark, Sheida Hajarian, and 
Caleb Farrel. A special thanks to Clay and Darla Schmalz for their assistance with various aspects of this project and the use of their trailer as home base for much of the fieldwork.

\section{Literature Cited}

Ainsworth, E.A., AND K.M. GiLLesPie. 2007. Estimation of total phenolic content and other oxidation substrates in plant tissues using Folin Ciocalteu reagent. Nature Protocols 2:875-877.

Ashworth, J., D. Keyes, R. KirK, and R. Lessard. 2001. Standard procedure in the hydrometer method for particle size analysis. Communications in Soil Science and Plant Analysis 32:633-642.

Dimitriadis, E., and P. Williams. 1984. The development and use of a rapid analytical technique for estimation of free and potentially volatile monoterpene flavorants of grapes. American Journal of Enology and Viticulture 35:66-71.

ELLISON, L. 1960. Influence of grazing on plant succession of rangelands. Botanical Review 26:1-78.

EsTES-ZumpF, W.A., AND J.L. RACHLOW. 2007. Evaluation of radio-transmitters on juvenile rabbits: application to the semifossorial pygmy rabbit (Brachylagus idahoensis). Western North American Naturalist 67:133-136.

Flinders, J.T. 1999. Pygmy rabbit, Brachylagus idahoensis. Pages 681-683 in D.E. Wilson and S. Ruff, editors, The Smithsonian Book of North American Mammals. Smithsonian Books, Washington, DC.

Flinders, J.T., AND R.M. Hansen. 1972. Diets and habitats of jackrabbits in northeastern Colorado. Range Science Department Science Serial No. 12, Colorado State University, Fort Collins, CO.

FreEland, W.J., AND D.H. JanZEN. 1974. Strategies in herbivory by mammals: the role of plant secondary compounds. American Naturalist 108:269-289.

Gabler, K.I., L.T. Heady, and J.W. Laundré. 2001. A habitat suitability model for pygmy rabbits (Brachylagus idahoensis) in southeastern Idaho. Western North American Naturalist 61:480-489.

GAHR, M.L. 1993. Natural history, burrow habitat and use, and home range of the pygmy rabbit (Brachylagus idahoensis) of Sagebrush Flat, Washington. Doctoral dissertation, University of Washington, Seattle, WA.

Green, J.S., And J.T. Flinders. 1980a. Brachylagus idahoensis. Mammalian Species 125:1-4.

1980b. Habitat and dietary relationships of the pygmy rabbit. Journal of Range Management 33: 136-142.

HEADY, L.T., AND J.W. LaundRÉ. 2005. Habitat use patterns within the home range of pygmy rabbits (Brachylagus idahoensis) in southeastern Idaho. Western North American Naturalist 65:490-500.

Jolliffe, I. 2005. Principal component analysis. 2nd edition. Springer, New York, NY.

Katzner, T.E., and K.L. Parker. 1998. Long-distance movements from established burrow sites by pygmy rabbits (Brachylagus idahoensis) in southwestern Wyoming. Northwestern Naturalist 79:72-74.

Katzner, T.E., K.L. Parker, and H.H. Harlow. 1997. Metabolism and thermal response in winter-acclima- tized pygmy rabbits (Brachylagus idahoensis). Journal of Mammalogy 78:1053-1062.

Larrucea, E.S. 2008. Distribution, behavior, and habitat preferences of the pygmy rabbit (Brachylagus idahoensis) in Nevada and California. Doctoral dissertation, University of Nevada, Reno, NV.

Larrucea, E.S., and P.F. Brussard. 2008. Habitat selection and current distribution of the pygmy rabbit in Nevada and California, USA. Journal of Mammalogy 89:691-699.

MacCracken, J.G., and R.M. Hansen. 1984. Seasonal foods of blacktail jackrabbits and Nuttall cottontails in southeastern Idaho. Journal of Range Management 37:256-259.

National Research Council. 1997. Nutrient requirements of rabbits. 2nd revised edition. National Academies Press, Washington, DC.

Pierce, J.E., R.T. Larsen, J.T. Flinders, and J.C. Whiting. 2011. Fragmentation of sagebrush communities: does an increase in habitat edge impact pygmy rabbits? Animal Conservation 14:314-321.

Rachlow, J.L., AND L.K. Svancara. 2006. Prioritizing habitat for surveys of an uncommon mammal: a modeling approach applied to pygmy rabbits. Journal of Mammalogy 87:827-833.

Sanchez, D.M., J.L. Rachlow, A.P. Robinson, and T.R. JOHNSON. 2009. Survey indicators for pygmy rabbits: temporal trends of burrow systems and pellets. Western North American Naturalist 69:426-436.

Shipley, L.A., T.B. Davila, N.J. Thines, and B.A. Elias. 2006. Nutritional requirements and diet choices of the pygmy rabbit (Brachylagus idahoensis): a sagebrush specialist. Journal of Chemical Ecology 32: 2455-2474.

Shipley, L.A., E.M. Davis, L.A. Felicetti, S. McLean, AND J. Sorensen Forbey. 2012. Mechanisms for eliminating monoterpenes of sagebrush by specialist and generalist rabbits. Journal of Chemical Ecology 38:1178-1189.

Siegel Thines, N.J., L.A. Shipley, and R.D. Sayler. 2004. Effects of cattle grazing on ecology and habitat of Columbia Basin pygmy rabbits (Brachylagus idahoensis). Biological Conservation 119:525-534.

UlapPa, A.C. 2011. Nutritional and chemical factors shaping diet selection for two sagebrush specialists: pygmy rabbits and sage-grouse. Master's thesis, Boise State University, Boise, ID.

WeIss, N.T., AND B. VerTS. 1984. Habitat and distribution of pygmy rabbits (Sylvilagus idahoensis) in Oregon. Western North American Naturalist 44:563-571.

White, S.M., J.T. Flinders, And B.L. Welch. 1982. Preference of pygmy rabbits (Brachylagus idahoensis) for various populations of big sagebrush (Artemisia tridentata). Journal of Range Management 35:724-726.

WILDE, D.B. 1978. A population analysis of the pygmy rabbit (Sylvilagus idahoensis) on the INEL site. Doctoral dissertation, Idaho State University, Pocatello, ID.

Wilson, T.L., J.B. OdeI, M.B.Hooten, and T.C. EdWARds JR. 2010. Hierarchical spatial models for predicting pygmy rabbit distribution and relative abundance. Journal of Applied Ecology 47:401-409.

Received 22 October 2013 Accepted 22 September 2014 